\title{
Evaluation of Crataeva nurvala extracts as antioxidant, antiproteolytic and cytotoxic against hepato-carcinoma and mouse melanoma cell lines
}

\author{
Swati N. Hade, Prachi A. Joshi, Harshda H. Pilley, Varsha P. Wadegaonkar, Prasad A. Wadegaonkar* \\ Department of Biotechnology, Sant Gadge Baba Amravati University, Amravati-444602, India.
}

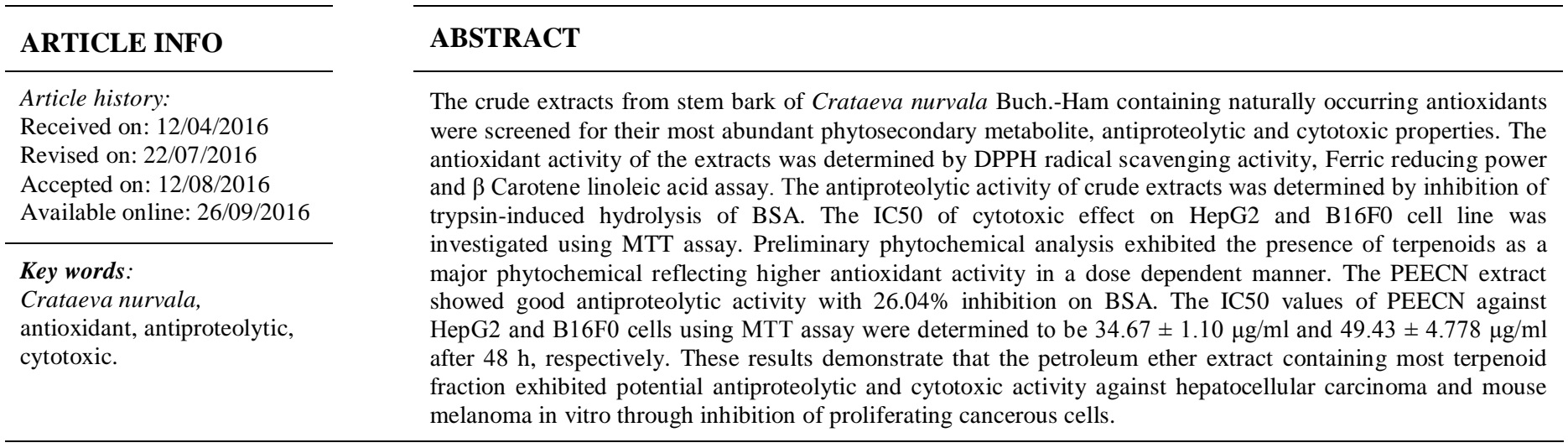

\section{INTRODUCTION}

Oxidative metabolism is essential to the survival of cells. A side effect of this dependence is the production of free radicals and other reactive oxygen species (ROS) that causes oxidative changes (Valko et al., 2007). The oxidative stress can be contributed either by the cells generating ROS as part of normal aerobic metabolism or by the ROS generated secondary to plant and animal responses to injury and invading organisms or by the ROS generated in polluted atmospheres. The oxidative stress could mediate damage to cell structures, including lipids, proteins, RNA and DNA, which lead to a number of diseases (Cohen, 1907; Antolovich et al., 2002). The lack of antioxidants facilitates the development of degenerative diseases, including

\footnotetext{
* Corresponding Author

Prasad A. Wadegaonkar, Department of Biotechnology,

Sant Gadge Baba Amravati University, Amravati 444602 India.

Email: prasadwadegaonkar@sgbau.ac.in
}

cardiovascular diseases, cancers, neurodegenerative diseases, Alzheimer's disease and inflammatory diseases. The therapeutic uses of traditional medicinal products in various inflammatory diseases and cancers have been generally observed. The ethnopharmacological usages of traditional plants for the treatment of skin disorders, inflammatory and other infectious diseases can be taken into account because they reflect disease states bearing relevance to cancer or a cancer symptom. The efforts have been made to discover new therapeutic agents from traditional medicinal plants that lack the toxic effects associated with current therapeutic agents (Ruffa et al., 2002).

The extracellular processes usually require the release of a preformed substance such as anti-inflammatory defenses or anticoagulation, which do so by using proteases, specifically, proteases that have the amino acid residue serine at their active site. Human serine proteases, which have actions with regard to inflammation, are thrombin, kallikrein, trypsin, elastase, and cathepsin (Bilfinger et al., 2002). 
The antitumor activity of medicinal plant derived compounds may result from a number of mechanisms, including effects on cytoskeletal proteins that play a key role in cell division, inhibition of DNA topoisomerase enzymes, antiprotease, antioxidant activity, stimulation of the immune system, etc. (Dixit et al., 2010).

The Crataeva nurvala Buch. Ham. (Family Capparidaceae) is one of such plants that are ethnopharmacologically important and is used for the treatment of various disorders. The plant parts of $C$. nurvala are commonly applied to regulate equilibrium among vata (blood flow, waste elimination and breathing), pitta (fever and metabolic disorder) and kapha (joint lubrication, skin moisture, wound healing, strength and vigor, memory loss, heart and lung weakness and weak immune system) in Ayurvedic system (Warrier et al., 1995). It is a medium sized branched deciduous plant distributed throughout the river banks of southern India and other tropical, sub-tropical countries around the world, wild or cultivated (Soosamma et al., 2010). The trade name of this tree is three-leaved capper as it contains "tri-parna" or trifoliate leaves, commonly known as 'Varuna', is an evergreen tree indigenous to India (Venkatachalapathi et al., 2012). The tree develops flowers and fruits in December-May and June-August (Sikarwar et al., 2010).

The present study was to assess the phytochemical content, antioxidant, anti-proteolytic and cytotoxic activity of methanolic and petroleum ether extracts from stem barks of $C$. nurvala. This paper mainly discusses the anti-proteolytic and cytotoxic properties of terpenoids as it plays an important role in investigating anticancerous virtues. This systematic investigation of $C$. nurvala plant extracts for its medicinal properties would provide valuable input to the pharmaceutical industry.

\section{MATERIALS AND METHODS}

\section{Chemicals}

2,2-diphenyl-1-Picrylhydrazyl (DPPH), Ferric Chloride $\left(\mathrm{FeCl}_{3}\right)$, Potassium Ferricyanide $\left[\mathrm{K}_{3} \mathrm{Fe}(\mathrm{CN})_{6}\right]$, Trichloroacetic acid, monobasic Sodium Phosphate, disodium Phosphate, $\beta$ Carotene, Linoleic acid, Tween-20, Bovine Pancreatic Trypsin, Bovine Serum Albumin (BSA), Ascorbic acid, Quercetin, Salicylic acid, MTT (3-(4,5-dimethylthiazol-2-yl)-2,5 diphenyltetrazolium bromide), DMSO(Dimethyl sulphoxide), EDTA(Ethylene diamine tetra acetic acid, trypan blue, Phosphate buffer saline (PBS) were purchased from Himedia Laboratories Pvt. Ltd. (Bangalore, India). All other chemicals and solvents used were of analytical grade. The B16F0 (Mouse melanoma cell line) and HepG2 (Hepatocarcinoma cell line) were procured from National Centre for Cell Sciences (NCCS), Pune and cultured in their respective medium in a T24 culture flask.

\section{Plant material}

The stem barks of Crataeva nurvala were collected from Sanjay Gandhi National Park, Borivali, Mumbai,(Maharashtra).
The plant was identified and confirmed by the taxonomist. The herbarium was deposited and authenticated at Botanical Survey of India, Pune, Maharashtra. The bark samples were collected from healthy plants. They were allowed to air dry under shade for seven days followed by oven dry at $45^{\circ} \mathrm{C}$ for two days. The dried stem bark materials were ground into a fine powder using clean, dry blender and then stored in airtight bottles.

\section{Preparation of the plant extract}

The methanol extract (MECN) and petroleum ether extract (PEECN) of Crataeva nurvala were prepared by soaking 9 $\mathrm{g}$ each of the dried powder plant materials in $300 \mathrm{ml}$ of respective solvent using a soxhlet extractor continuously for 12 hours. The extracts were then filtered through Whatman filter paper No. 42 $(125 \mathrm{~mm})$ to remove all non-extractable matter, including cellular materials and other constitutions that are insoluble in the extraction solvent. The entire extracts were concentrated to dryness using a rotary evaporator under reduced pressure. The final dried samples were stored in labeled sterile bottles and kept at $-20^{\circ} \mathrm{C}$. The percentage yields of the crude extracts were found to be $7.29 \%$ and $5.77 \%$ for solvents such as Methanol and Petroleum ether respectively.

\section{Phytochemical screening}

Phytochemical screening of the stem bark of Crataeva nurvala was carried out by using the standard protocols. The stem extract was screened for the presence of alkaloids, phenolic compounds, flavanoids, tannins, saponin, steroids, and terpenoids using the methods as described by Vanden Berghe et al., 2013.

\section{Antioxidant activity \\ DPPH free radical scavenging assay}

The DPPH radical scavenging activity was measured by the method, described by Sánchez-Moreno et al., 1998 with modifications. The sample stock solution $(1 \mathrm{mg} / \mathrm{ml})$ was diluted to a final concentration of $100,200,400,600,800,1000 \mu \mathrm{g} / \mathrm{ml}$ in methanol. A total of $2 \mathrm{ml}$ of freshly prepared DPPH solution $(0.3 \mathrm{mM})$ was added to $2 \mathrm{ml}$ of sample solution of different concentration and was allowed to react at $37^{\circ} \mathrm{C}$ in the dark for 45 min. The absorbance was measured at $517 \mathrm{~nm}$. The antioxidant activity was calculated in percent using following formula.

DPPH radical scavenging activity $(\%)$

$$
=\frac{(\text { Absorbance of control }- \text { Absorbance of sample })}{(\text { Absorbance of control })} \times 100
$$

Ascorbic acid was used as positive control. The DPPH solution plus methanol was used as a negative control. The $\mathrm{IC}_{50}$ value is the sample concentration required to scavenge $50 \%$ of the DPPH free radicals. It was calculated using nonlinear regression analysis of dose-dependent curves.

\section{Ferric reducing power assay}

The reducing power assay of stem bark sample of $C$. nurvala was carried out as described by (Duh et al., 1999). The 
solvent extracts of bark sample i.e., MECN and PEECN at different concentrations $(200 \mu \mathrm{g}-1000 \mu \mathrm{g} / \mathrm{ml})$ were mixed with Phosphate buffer $(2.5 \mathrm{ml}, 0.2 \mathrm{M}, \mathrm{pH}$ 6.6) and potassium ferricyanide $(2.5 \mathrm{ml}, 1 \%)$.

The mixture was incubated at $50^{\circ} \mathrm{C}$ for $20 \mathrm{~min}$. A portion $(2.5 \mathrm{ml})$ of trichloroacetic acid $(10 \%)$ was added to the mixture which was then centrifuged at $3000 \mathrm{rpm}$ for $10 \mathrm{~min}$. The upper layer of the solution $(2.5 \mathrm{ml})$ was mixed with distilled water $(2.5 \mathrm{ml})$ and ferric chloride $(0.5 \mathrm{ml}, 0.1 \%)$ and the absorbance was measured at $700 \mathrm{~nm}$ and compared with ascorbic acid as a standard. The increased absorbance of the reaction mixture indicated increased reducing power.

\section{$\beta$ - Carotene linoleic acid assay}

Antioxidant activity based coupled oxidation of $\beta$ carotene and linoleic acid was evaluated by some modification to the method described by (Miller, 1971; Taga et al., 1984; Arya et al., 2011). Two $\mathrm{mg} \beta$ carotene was dissolved in $20 \mathrm{ml}$ of chloroform. Linoleic acid $40 \mathrm{mg}$ and Tween-20 $400 \mathrm{mg}$ were added to the $13 \mathrm{ml}$ aliquot of the solution in a $50 \mathrm{ml}$ flask. Chloroform was evaporated at $45^{\circ} \mathrm{C}$. Oxygenated distilled water $(100 \mathrm{ml})$ was added into $\beta$ carotene emulsion and mixed well by using a vortex mixer.

Aliquots of $3 \mathrm{ml}$ of the oxygenated $\beta$ carotene emulsion and $0.12 \mathrm{ml} \mathrm{MECN}$ and PEECN $(200-1200 \mu \mathrm{g} / \mathrm{ml})$ were placed in capped culture tubes and mixed thoroughly. The tubes were immediately placed into a water bath and incubated at $50{ }^{\circ} \mathrm{C}$. The oxidation of $\beta$ carotene emulsion was monitored spectrophotometrically by measuring absorbance at $470 \mathrm{~nm}$. Absorbance was measured at 0, 10, 20, 30, 40 min. A control was prepared by using $0.12 \mathrm{ml}$ of methanol instead of methanolic extract.

The antioxidant activity of the plant extracts under investigation was expressed as:

$$
\% \mathrm{AA}=100\left(\frac{1-(\mathrm{A} 1(\mathrm{t}=0)-\mathrm{A} 1(\mathrm{t}=120))}{(\mathrm{A} 0(\mathrm{t}=0)-\mathrm{A} 0(\mathrm{t}=120))}\right)
$$

Where,

$\% \mathrm{AA}=$ Antioxidant activity of the plant extract

$\mathrm{A}_{1(\mathrm{t}=0)} \quad=$ Absorbance of the test sample/standard at zero time

$\mathrm{A}_{1(\mathrm{t}=120)}=$ Absorbance of the test sample/standard after $120 \mathrm{~min}$

$\mathrm{A}_{0(\mathrm{t}=0)} \quad=$ Absorbance of the aqueous control sample at zero time

$\mathrm{A}_{0(\mathrm{t}=120)}=$ Absorbance of the aqueous control sample after $120 \mathrm{~min}$

\section{Antiproteolytic Assay}

The anti-proteolytic activity stem bark extracts of the plant was evaluated by trypsin-induced hydrolysis of BSA (Gacche et al., 2006). The test sample $(0.5 \mathrm{ml})$ with individual concentrations of MECN and PEECN $(50-200 \mu \mathrm{g} / \mathrm{ml})$ was added to trypsin $(0.075 \mathrm{mg} / \mathrm{ml})$ and incubated for $20 \mathrm{~min}$. The substrate, bovine serum albumin $(6 \mathrm{~g} / 100 \mathrm{ml}$, in $0.1 \mathrm{M}$ Phosphate buffer, $\mathrm{pH}$ 7.6) was added and after $20 \mathrm{~min}$ incubation at $37^{\circ} \mathrm{C}$, the reaction was terminated by the addition of $3 \mathrm{ml}$ Trichloroacetic acid (5\%, $\mathrm{w} / \mathrm{v})$. The extent of hydrolysis was determined after trichloroacetic acid precipitation of unreacted substrate, as the amount of peptides present in the clear supernatant.

The mixture was centrifuged at $5000 \mathrm{rpm}$ for $10 \mathrm{~min}$ and the acid soluble fraction obtained in the supernatant was subjected to protein determination by the Folin-Lowry method (Stauffer, 1975). Enzyme blanks were prepared by adding the TCA solution to the reaction mixture immediately after substrate addition. Salicylic acid (1mM) was used as a standard.

\section{In vitro cytotoxicity assay Antiproliferative Assay}

In vitro antiproliferative assay was determined using MTT [3-(4,5-dimethylthiazol-2-yl)-2,5 diphenyltetrazolium bromide] activity based upon $\mathrm{IC}_{50}$ values of metabolically active mitochondria of B16F0, HepG2 cells at their logarithmic phase. Briefly, $100 \mu \mathrm{l}$ of cell culture was seeded in a 96 well-plate containing complete medium and treated with different concentrations $(1-20 \mu \mathrm{g} / \mathrm{ml})$ of MECN and PEECN in DMSO. After incubation for $48 \mathrm{hr}$ at $37{ }^{\circ} \mathrm{C}$ in a humidified $\mathrm{CO}_{2}$ incubator, $50 \mu \mathrm{l}$ of MTT $(1 \mathrm{mg} / \mathrm{ml})$ was added to each well and incubated for another $4 \mathrm{~h}$.

The medium was removed carefully and $150 \mu \mathrm{l}$ of DMSO was then added to each well to solubilize the formazan blue crystals produced by viable cells. After complete dissolution of crystals, the absorbance was measured at 570nm using Robonik readwell plate analyzer. The final concentration of DMSO was $0.2 \%$ in all treatment. The percentage of cell viability was calculated according to the following equation described in (Denizot et al., 1986).

$\%$ cell viability $=\left(\frac{\text { OD of treated cells }}{\text { OD of control cells }}\right) \times 100$

\section{Statistical Analysis}

The experimental data were expressed as Mean $\pm \mathrm{SD}$. The inhibitory concentrations $50 \%\left(\mathrm{IC}_{50}\right)$ was calculated by plotting the data in the graph as concentration versus percentage inhibition using (Brana et al., 2002) Prism software. The significance of the difference from the respective controls for each experimental test condition was assayed by using One-way ANOVA test for repeated measures $(n=3)$ with Dunnett's post test.

\section{RESULT}

\section{Phytochemical screening}

The preliminary phytochemical screening of stem bark of Crataeva nurvala was carried out using standard chemical tests. This revealed the presence of steroid and terpenoids as well as alkaloids, phenolics, flavanoids, tannin and saponin as reported in Table 1. These compounds are known to be pharmacologically active and, therefore, aids to the various biological activities of $C$. nurvala. 
Table 1: Qualitative analysis of phytoconstituents from stem bark of C. nurvala.

\begin{tabular}{|c|c|c|c|c|c|c|c|c|c|c|c|}
\hline \multirow{3}{*}{ Crude Extracts } & \multirow{3}{*}{$\begin{array}{l}\text { Percent } \\
\text { Yield }\end{array}$} & \multicolumn{10}{|c|}{ Phytochemical Tests } \\
\hline & & \multirow{2}{*}{$\begin{array}{c}\text { Terpenoid } \\
\begin{array}{c}\text { Salkowski } \\
\text { Test }\end{array}\end{array}$} & \multirow{2}{*}{$\begin{array}{c}\begin{array}{c}\text { Steroid And } \\
\text { Terpenoids }\end{array} \\
\text { Lieberman- } \\
\text { Burchard Test }\end{array}$} & \multirow{2}{*}{$\frac{\frac{n}{0}}{\frac{E}{E}}$} & \multirow{2}{*}{ 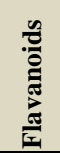 } & \multicolumn{4}{|c|}{ Alkaloids } & \multirow{2}{*}{ 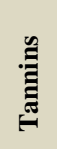 } & \multirow{2}{*}{ 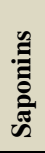 } \\
\hline & & & & & & $\begin{array}{l}\text { Mayer's } \\
\text { Reagent }\end{array}$ & $\begin{array}{c}\text { Dragendroff's } \\
\text { Reagent }\end{array}$ & $\begin{array}{l}\text { Hager's } \\
\text { Reagent }\end{array}$ & $\begin{array}{l}\text { Wagner's } \\
\text { Reagent }\end{array}$ & & \\
\hline Methanol & 7.29 & ++ & + & ++ & ++ & ++ & + & + & ++ & + & + \\
\hline Petroleum Ether & 5.77 & ++ & ++ & - & - & + & + & - & + & - & - \\
\hline
\end{tabular}

(+ moderately present, ++ strongly present, - absent).

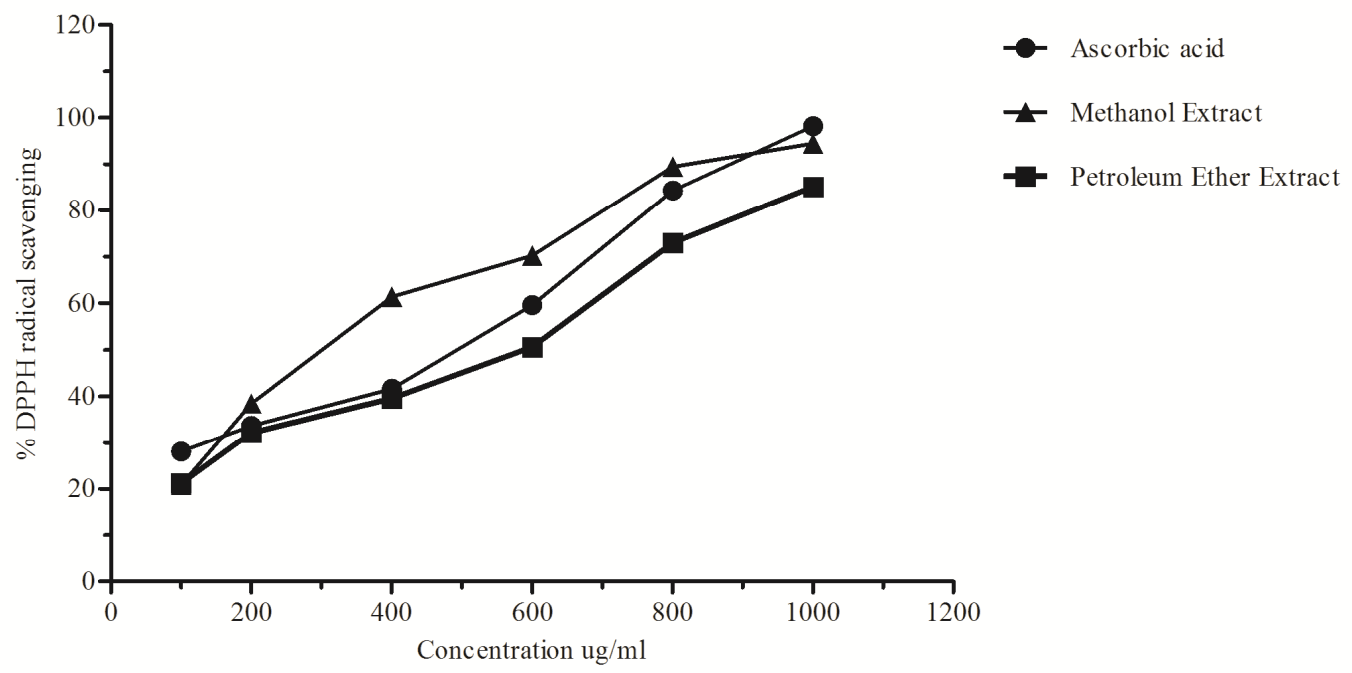

Fig 1: DPPH radical scavenging activity (Mean $\pm \mathrm{SD})$ of different extracts $(\mathrm{n}=3)$ of stem bark of $C$. nurvala.

\section{Antioxidant activity}

\section{DPPH free radical scavenging assay}

DPPH (2,2-diphenyl-2-picryl hydrazyl), a stable free radical, when acted upon by an antioxidant, is converted into diphenyl-picryl hydrazine with a color change from deep violet to light yellow color. This was quantified spectrophotometrically at $517 \mathrm{~nm}$ to indicate the extent of DPPH scavenging activity by the stem bark extracts of the plant. The results of the various extract of DPPH radical scavenging activity of $C$. nurvala $(\mathrm{n}=3)$ are shown in Figure 1 and Table 2.

Table 2: Antioxidant activities showing $\mathrm{IC}_{50}$ values (Mean $\pm \mathrm{SD}$ ) of different extracts of C. nurvala.

\begin{tabular}{llc}
\hline \multirow{2}{*}{ Extracts } & \multicolumn{2}{c}{$\mathbf{I C}_{\mathbf{5 0}}(\boldsymbol{\mu} \mathbf{g} / \mathbf{m l})$} \\
\cline { 2 - 3 } & \multicolumn{1}{c}{ DPPH Assay } & $\boldsymbol{\beta}$ - carotene linoleic acid assay \\
\hline Methanol & $363.125 \pm 13.25$ & $604.062 \pm 9.39$ \\
Petroleum ether & $518.55 \pm 12.19$ & $787.142 \pm 13.79$ \\
Ascorbic Acid & $426.875 \pm 16.4$ & $547.187 \pm 12.1$ \\
\hline
\end{tabular}

The scavenging effects of various extracts of $C$. nurvala and ascorbic acid as standard on the DPPH radical decreased in the order of methanol, ascorbic acid, and petroleum ether extract which were found to be $89.414 \pm 0.14,84.25 \pm 0.15$ and $72.931 \pm$ 2.01 at the concentration of $800 \mu \mathrm{g} / \mathrm{ml}$, respectively. These results indicated that the methanolic extracts of $C$. nurvala have a noticeable effect on scavenging free radicals and their activity was found to be increasing with increase in the dose. It was also found that there was no significant difference observed between the extracts $\mathrm{P}<0.05$.

The methanolic extract showed 50\% inhibition $\left(\mathrm{IC}_{50}\right)$ at $363.125 \pm 13.25 \mu \mathrm{g} / \mathrm{ml}$ and ascorbic acid which was used as a standard antioxidant compound, showed $\mathrm{IC}_{50}$ at $426.875 \pm$ $16.4 \mu \mathrm{g} / \mathrm{ml}$. Among different extracts of $C$. nurvala, the methanolic extract was found to be the most efficient antioxidant with lower $\mathrm{IC}_{50}$ than that of the petroleum ether. Thus, when compared with standard antioxidant, the methanolic extract of stem bark of $C$. nurvala showed better radical scavenging activity.

\section{Ferric reducing power assay}

Reducing power assay measures the electron donating capacity of an antioxidant. The reduction of the ferric ion $\left(\mathrm{Fe}^{3+}\right)$ to ferrous ion $\left(\mathrm{Fe}^{2+}\right)$ is measured by the intensity of the resultant blue-green solution which absorbs at 700nm and an increased absorbance is indicative of higher reducing power. The Figure 2 shows the extent of reduction for the extracts ranging in concentration from $200 \mu \mathrm{g} / \mathrm{ml}$ to $1000 \mu \mathrm{g} / \mathrm{ml}$ and was compared with ascorbic acid as a positive control. The extracts exhibited dose-dependent reducing power potential with an ascorbic acid having the highest reduction potential. Among the $C$. nurvala bark extracts, the methanolic extract showed maximum ferric reducing power activity. 


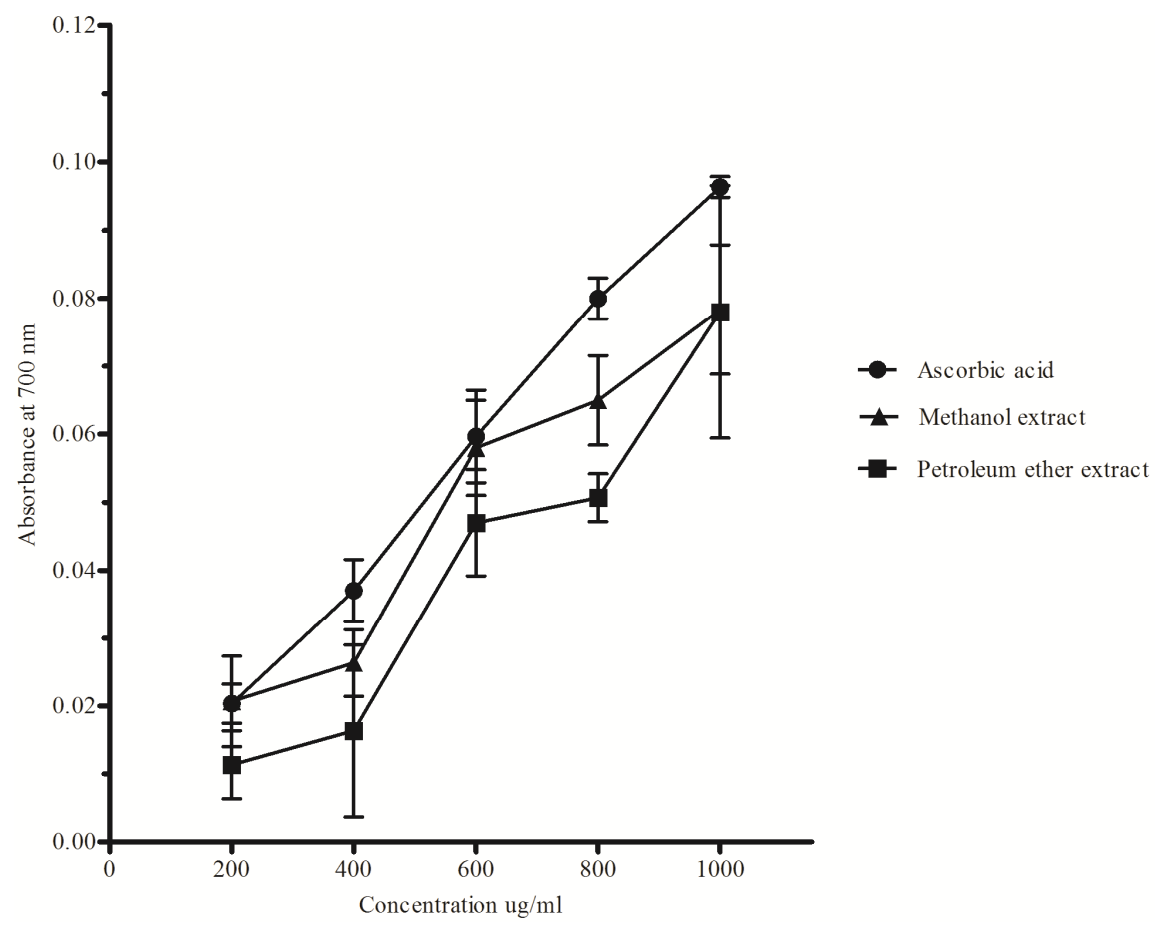

Fig. 2: Ferric Reducing power (Mean $\pm \mathrm{SD}$ ) of different extracts $(\mathrm{n}=3)$ of stem bark of $C$. nurvala.

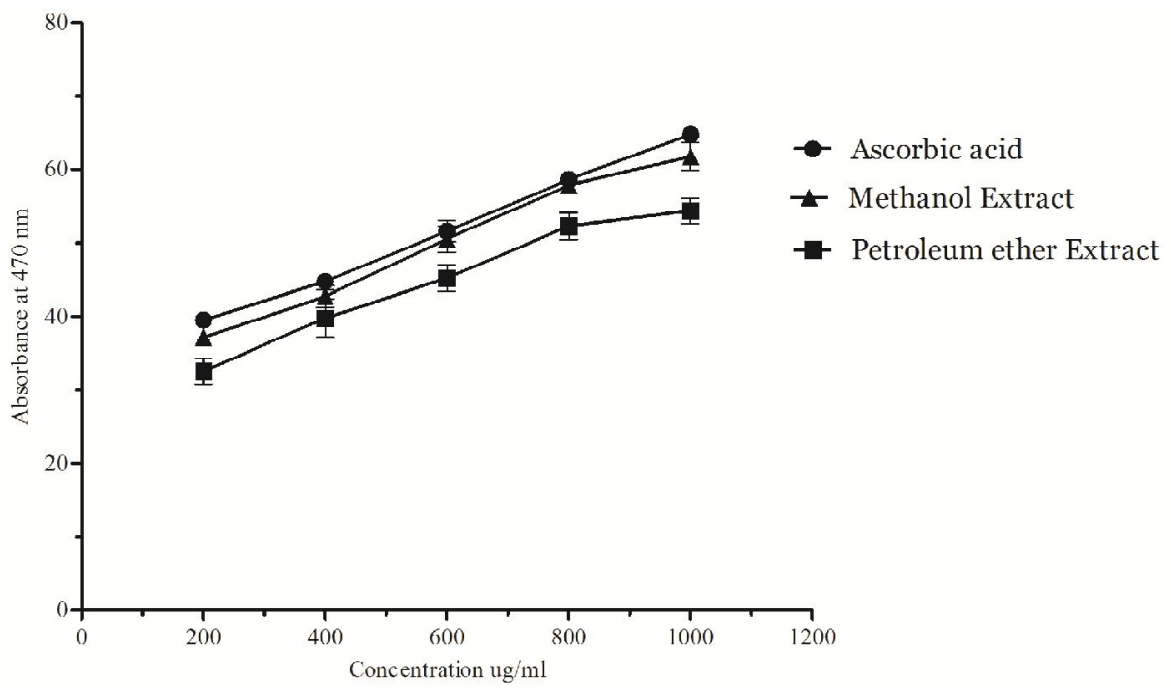

Fig. 3: Antioxidant activity of MECN and PEECN determined with $\beta$ carotene linoleic acid model system.

\section{$\beta$ - Carotene linoleic acid assay}

In the $\beta$-carotene/linoleic acid method, the bleaching mechanism of $\beta$-carotene is a free radical mediated phenomenon resulting from the formation of hydroperoxides from linoleic acid oxidation. In the absence of an antioxidant, $\beta$-carotene will undergo rapid discoloration. The addition of the antioxidant containing extracts can protect the extent of $\beta$-carotene orange color by neutralizing the peroxide products which were formed from linoleic acid. Hence, the high absorbance values indicated that highest antioxidant activity. In this method, the results were consistent with the data obtained from the DPPH test except that of standard ascorbic acid (44.716 \pm 1.14$)$ showing slight better antioxidant activity to that of methanolic extract $(42.713 \pm 1.645)$ at a concentration of $400 \mu \mathrm{g} / \mathrm{ml}$ (Figure 3). There was no significant difference observed between standard and methanolic extract at $\mathrm{P}$ $<0.05$, statistically. Among the extracts, the percent antioxidant activity of methanolic extracts was found to be greatest, followed by petroleum ether extract.

In this method, antioxidant activity of ascorbic acid was found to be least, followed by methanolic extract with an $\mathrm{IC}_{50}$ value of $604.062 \pm 9.39 \mu \mathrm{g} / \mathrm{ml}$, which was found to be more effective than petroleum ether extract. 


\section{Antiproteolytic Assay}

The inhibition of trypsin-induced hydrolysis of bovine serum albumin was used as a model proteolytic system for investigating anti-proteolytic activities of $C$. nurvala. The result shown in Table 3 indicates that the petroleum ether extract (26.04\%) can be graded as the most effective anti-proteolytic agent which was followed by methanol $(19.62 \%)$. The salicylic acid $(20.63 \%)$ was used as a standard. The inhibitory concentration of trypsin by the petroleum ether extract of $C$. nurvala $\left(\mathrm{IC}_{50}=121.36\right.$ $\mu \mathrm{g} / \mathrm{ml}$ ) was graded as the most effective anti-proteolytic sample as compared to other extracts.

Table 3: The percent inhibition of trypsin of different extracts of $C$. nurvala.

\begin{tabular}{cccc}
\hline \multicolumn{3}{c}{ Percent Trypsin Inhibition } \\
\hline $\begin{array}{c}\text { Concentration } \\
\boldsymbol{\mu g} / \mathbf{m} \mathbf{l}\end{array}$ & Methanol $^{\mathbf{a}}$ & Petroleum ether $^{\mathbf{b}}$ & Salicylic Acid $^{\mathbf{a}}$ \\
\hline 200 & 19.62 & 26.04 & 20.63 \\
150 & 10.91 & 20.95 & 15.33 \\
100 & 9.27 & 11.89 & 10.02 \\
50 & 7.09 & 10.75 & 7.07 \\
\hline
\end{tabular}

$\left({ }^{\mathrm{a}, \mathrm{b}}\right.$ Different letters indicates significant difference at $\left.P<0.05\right)$.
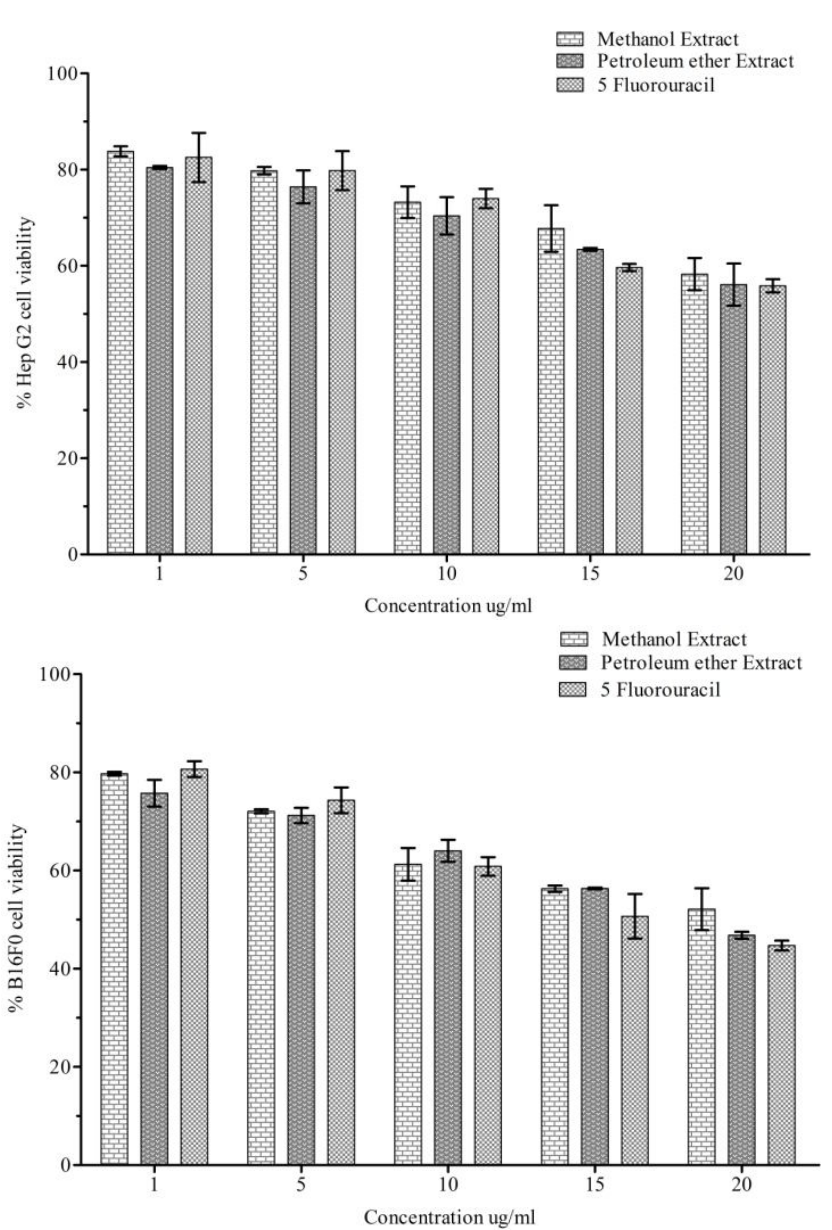

Fig. 4: In vitro cytotoxic effect of PEECN and MECN on (A) Hep G2 and (B) $\mathrm{B} 16 \mathrm{~F} 0$ cells by trypan blue exclusion assay. All values are mean $\pm \mathrm{SD}$ of three samples

\section{Invitro antiproliferative assay (MTT Assay)}

The antiproliferative activity of methanolic and petroleum ether extract of $C$. nurvala was assessed in vitro using
MTT assay on HepG2 and B16F0 cell line. It was observed that the MECN, PEECN and 5-FU showed inhibitory effects on the growth and proliferation of HepG2 and B16F0 cells in a dosedependent manner (Fig. 5).
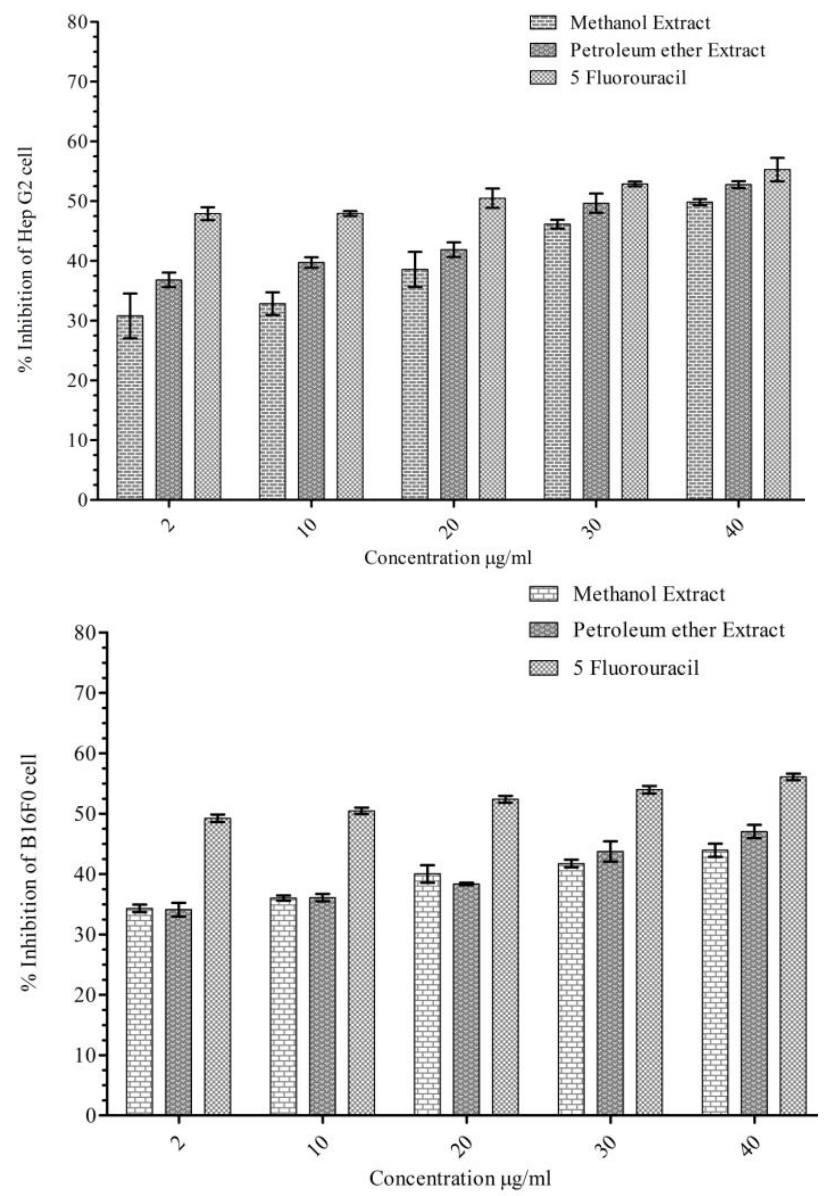

Fig. 5: The cytotoxic effect of PEECN and MECN on (A) Hep G2 and (B) B16F0 cells using MTT assay after $48 \mathrm{hrs}$ of exposure to the extracts. The data are reported as mean \pm SD of three independent experiments.

The PEECN has shown to be having a better inhibitory effect than the MECN after 48 hrs of cell treatment as compared to control, in the concentration range of $2-40 \mu \mathrm{g} / \mathrm{ml}$. The linear regression analysis was used to estimate half-maximal $\left(\mathrm{IC}_{50}\right)$ antiproliferative effects of the extract. The $\mathrm{IC}_{50}$ value of PEECN $(34.67 \pm 1.10 \mu \mathrm{g} / \mathrm{ml})$ was found to be better than MECN $(41.45 \pm$ $0.857 \mu \mathrm{g} / \mathrm{ml}$ ) in HepG2 cell line. Similarly, in the case of B16F0 cell line, the $\mathrm{IC}_{50}$ value of PEECN $(49.43 \pm 4.778 \mu \mathrm{g} / \mathrm{ml})$ was better than that of MECN $(79.24 \pm 5.45 \mu \mathrm{g} / \mathrm{ml})$. The $\mathrm{IC}_{50}$ value of 5 -FU was found to be $(7.04 \pm 1.763 \mu \mathrm{g} / \mathrm{ml}) \mathrm{B} 16 \mathrm{~F} 0$ cell line and $(16.17 \pm 4.285 \mu \mathrm{g} / \mathrm{ml})$ for HepG2 cell line. Similar inhibitory effects were observed at higher concentrations of PEECN and 5FU treated HepG2 cell lines.

\section{DISCUSSION}

Plants have been the basis of traditional medicines throughout the world for thousands of years providing new remedies to humankind (Krishnaiah et al., 2011). The medicinal 
property of any plant has been attributed by phytochemicals present within the plant. These phytochemicals are the nonnutritional plant compounds that are produced by the plants in selfdefense to protect them from pest, microbes, and environmental stress factors. In past, different phytochemical compounds from herbs and plants have been used for the development of new drugs (Kumar et al., 2013). In medicinal plant world, there are a huge number of diverse bioactive compounds with antioxidant activity that play a significant role in terminating the generation of free radical chain reactions. Insufficient dietary antioxidant failed to control the oxidative stress and need to be supported by antioxidant supplements. The rejection by consumers towards the synthetic antioxidants due to undesirable side effects provides an opportunity to discover natural antioxidant. Therefore, many experimental techniques are focused on identifying natural antioxidants from plants (Basma et al., 2011). In this preliminary pharmacological investigation, we have investigated the phytochemical composition; antioxidant activity, anti-proteolytic and cytotoxic activity of the two solvent extracts of $C$. nurvala stem bark. The results of a phytochemical study of a various solvent extract of the $C$. nurvala stem bark are in agreement with the previous studies where extracts of other Crataeva species have been reported (Bhattacharjee et al., 2012). The terpenoids have been found in the maximum amount in extracts of methanol and petroleum ether. The antioxidant activities of natural antioxidants have been attributed to various mechanisms, such as prevention of chain initiation, binding with transition metal ion catalysts, decomposition of peroxides, prevention of continued hydrogen abstraction, reducing capacity and radical scavenging ability (Liu et al., 2013). The proton radical scavenging action is one of the important mechanisms of antioxidants. The scavenging of stable DPPH radical is a widely used method to evaluate antioxidant activity and the effect of antioxidants on DPPH radical scavenging is a result of their hydrogen donating ability (Mohamed et al., 2009). Reducing power also serves as a significant reflection of the antioxidant activity. The compounds with reducing power indicate that they are electron donors and can reduce the oxidized intermediates of lipid peroxidation processes, so that they can act as primary and secondary antioxidants (Ikeura et al., 2010). In the reducing power assay, the presence of antioxidants in the samples would result in the reducing of $\mathrm{Fe}^{3+}$ to $\mathrm{Fe}^{2+}$ by donating an electron. The ability of $\beta$-carotene and its degradation products to undergo single electron transfer-based reaction was utilized in the analysis of ferric reducing activity (Mueller et al., 2011). In our investigation of the antioxidant assay in stem bark of $C$. nurvala, the free radical scavenging capacity and ferric reducing capacity reflects higher antioxidant potential in methanolic extract followed by petroleum ether. In the case of $\beta$-carotene/linoleic acid assay, the antioxidant efficacy of methanol and petroleum ether was found to be slightly lower than that of the positive control ascorbic acid. This work thereby suggests that methanol and petroleum ether extracts of $C$. nurvala stem bark showed good antioxidant property, and it possesses a higher amount of terpenoids. This implies that the antioxidant property may be due to terpenoids.
These natural antioxidant properties of terpenoids have also been reported in many plant species (Graßmann, 2005; Krishnaiah et al., 2011). Free radicals react with main cellular components like proteins and lipids and in this way modify proteolyticantiproteolytic balance and enable penetration damaging cellular membrane. These lead to enhancement of proteolysis and destruction of extracellular matrix protein and in consequence to invasion and metastasis (Skrzydlewska et al., 2005). Proteases, especially serine proteases are key players in recruiting the initiation and progression of the inflammatory process. Moreover, serine protease inhibition has been considered as one of the targets for designing the anti-inflammatory agents (Gacche et al., 2008). In trypsin-induced hydrolysis of bovine serum albumin assay, petroleum ether extract shows strong inhibitory action against serine protease-like trypsin. This terpene mediated antiprotease activity has also been reported by many natural terpenoids from other plant species (Banerji et al., 1983; Lynn et al., 2003).

A wide variety of diseases is known to be occurred due to an imbalance between protection against free radicals and their generation. The oxidative injury might induce gene mutation and promote carcinogenesis and antioxidants are believed to provide protection against cancer (Sardas, 2003). Thus, plant-based natural antioxidants provided a better reason to study about their deterrent action towards carcinogenesis. The MTT assay was performed to measure the rate of cell proliferation which is a universal property of tumor cells. In this study cytotoxic effect of petroleum ether extract of $C$. nurvala on hepato-carcinoma and mouse melanoma cell line was found to be better than that of methanolic extract. According to the United States National Cancer Institute plant screening program, a crude extract is generally considered to have in vitro cytotoxic activity if the $\mathrm{IC}_{50}$ is $<30-40 \mu \mathrm{g} / \mathrm{mL}$ (Boik, 2001). The MTT screening of the antiproliferative activities of the C. nurvala extract determined that the PEECN was active $\left(\mathrm{IC}_{50}\right.$ : $34.67 \pm 1.10 \mu \mathrm{g} / \mathrm{ml})$ against HepG2 cell line whereas MECN $\left(\mathrm{IC}_{50}\right.$ : $41.45 \pm 0.857 \mu \mathrm{g} / \mathrm{ml}$ ) was found to be moderately active. Similarly, in the case of $\mathrm{B} 16 \mathrm{~F} 0$ cell line PEECN $\left(\mathrm{IC}_{50}: 49.43 \pm\right.$ $4.778 \mu \mathrm{g} / \mathrm{ml}$ ) was found to be weakly active and very little activity could be obtained in $\mathrm{MECN}\left(\mathrm{IC}_{50}: 79.24 \pm 5.45 \mu \mathrm{g} / \mathrm{ml}\right.$ ). In this study, petroleum ether extract of $C$. nurvala displayed the strong anti-cancer effect but moderate antioxidant activity. This suggests that the antioxidant activity and terpenoid content are unrelated with each other, whereas the anti-cancer activity does have terpenoid content as a major contributor. However, the inhibition of cancer cell proliferation by these two extracts of $C$. nurvala may not be wholly due to their terpenoid content but might be attributed to other bioactive compounds present as well as different active non-polar constituents present in the petroleum ether and methanol fraction.

\section{CONCLUSION}

We successfully screened the antioxidant and antiproliferative activities from the stem bark of $C$. nurvala using petroleum ether and methanol fractions. The methanol extract of 
C. nurvala has strong antioxidant capacity which was influenced mostly by terpenoid and alkaloid content. However, the petroleum ether extract containing most terpenoid fraction appeared to be showing potent anti-inflammatory activities. Hence, these activities cannot be linked to a single compound but may be due to additive or synergetic effects of the compounds in the extract. Future studies are required to investigate the action of $C$. nurvala extract on cellular toxicity and anti-inflammatory activities that would provide a better understanding for designing the lead molecule.

\section{ACKNOWLEDGMENT}

We would like to thank Department of Biotechnology, Govt. of India, for providing Bioinformatics Information System Network (BTISnet) at Department of Biotechnology, Sant Gadge Baba Amravati University, Amravati, Maharashtra.

Source of support: We would like to thank University Grant Commission, Govt. of India, for providing BSR fellowship to one of the authors.

Conflict of Interests: There are no conflicts of interest.

\section{REFERENCES}

Antolovich M, Prenzler PD, Patsalides E, McDonald S, Robards K. Methods for testing antioxidant activity. Analyst, 2002; 127:183-198.

Arya V, Yadav S, Kumar S and Yadav JP. Antioxidant activity of organic and aqueous leaf extracts of Cassia occidentalis L. in relation to their phenolic content. Nat Prod Res, 2011; 25:1473-1479.

Banerji R and Nigam S. Anti-proteolytic activity of some triterpenoids. Int J Crude Drug Res, 1983;21:93-95.

Basma AA, Zakaria Z, Latha LY, Sasidharan S. Antioxidant activity and phytochemical screening of the methanol extracts of Euphorbia hirta L. Asian Pac J Trop Med, 2011;4:386-390.

Bhattacharjee A, Shashidhara SC and Aswathanarayana. Phytochemical and ethnopharmacological profile of Crataeva nurvala Buch-Hum (Varuna): A review. Asian Pac J Trop Biomed, 2012; 2: S1162-S1168.

Bilfinger T and Stefano GB. The role of protease inhibition with emphasis on the effects of inflammation and vascular immune phenomena. Curr. Pharm. Des., 2002; 8:505-509.

Boik J. 2001. Natural compounds in cancer therapy. Minnesota, USA: Oregon Medical Press.

Brana C, Benham C, Sundstrom L. A method for characterizing cell death in vitro by combining propidium iodide staining with immunohistochemistry. Brain Res. Protoc, 2002; 10:109-114.

Cohen NH. Lupeol, $\alpha$ - und $\beta$-Amyrin aus Bresk. Archiv der Pharmazie, 1907; 245:236-245.

Denizot $\mathrm{F}$ and Lang R. Rapid colorimetric assay for cell growth and survival modifications to the tetrazolium dye procedure giving improved sensitivity and reliability. J Immunol Methods, 1986; 89: 271-77.

Dixit $\mathrm{S}$ and Ali $\mathrm{H}$. Anticancer activity of medicinal plant extract-a review. J Chem \& Chem Sci, 2010; 1:79-85.

Duh P-D, Tu Y-Y,Yen G-C. Antioxidant activity of water extract of Harng Jyur (Chrysanthemum morifolium Ramat). LWT-Food Sci and Technol, 1999; 32:269-277.

Gacche R, Khsirsagar M, Kamble S, Bandgar B, Dhole N, Shisode K, Chaudhari A. Antioxidant and Anti-inflammatory Related Activities of Selected Synthetic Chalcones: Structure-Activity Relationship Studies Using Computational Tools. Chem Pharm Bull, 2008; 56:897-901.

Gacche RN, Gond DS, Dhole NA, Dawane BS. Coumarin Schiff-bases: as antioxidant and possibly anti-inflammatory agents. J Enzyme Inhib Med Chem, 2006; 21:157-161.
J. Graßmann. Terpenoids as Plant Antioxidants. In: Gerald Litwack, Editor(s), Vitam. Horm, Academic Press, 2005; 72: 505-535.

Ikeura H, Kobayashi F, Hayata Y. Attractant and Oviposition Stimulant of Crataeva religiosa Forst. to Pieris rapae. Asian J Plant Sci, 2010; 9: 492-497.

Krishnaiah D, Sarbatly R, Nithyanandam R. A review of the antioxidant potential of medicinal plant species. Food Bioprod Process, 2011; 89:217-233.

Kumar G, Karthik L, Rao KVB. Phytochemical composition and in vitro antioxidant activity of aqueous extract of Aerva lanata (L.) Juss. ex Schult. Stem (Amaranthaceae). Asian Pac J Trop Med, 2013; 6:180-187.

Liu J, Jia L, Kan J, Jin CH. In vitro and in vivo antioxidant activity of ethanolic extract of white button mushroom (Agaricus bisporus). Food and chemical toxicology : an international journal published for the British Industrial Biological Research Association, 2013; 51:310-316.

Lynn DH, George KO, Theodore AM. Antiprotease effect of anti-inflammatory lupeol esters. Mol Cell Biochem, 2003; 252:97-101.

Miller H. A simplified method for the evaluation of antioxidants. J. Am. Oil Chem. Soc, 1971; 48:91-91.

Mohamed AA, Khalil AA, El-Beltagi HES. Antioxidant and antimicrobial properties of kaff maryam Anastatica hierochuntica and doum palm Hyphaene thebaica. Grasas y Aceites, 2009; 61:67-75.

Mueller L, Boehm V. Antioxidant activity of beta-carotene compounds in different in vitro assays. Molecules, 2011; 16:1055-1069.

Ruffa MJ, Ferraro G, Wagner ML, Calcagno ML, Campos RH, Cavallaro L. Cytotoxic effect of Argentine medicinal plant extracts on human hepatocellular carcinoma cell line. J Ethnopharmacol, 2002; 79:335-339.

Sánchez-Moreno C, Larrauri JA, Saura-Calixto F. A procedure to measure the antiradical efficiency of polyphenols. J Sci Food Agric, 1998; 76:270-276.

Sardas S. The Role of Antioxidants in Cancer Prevention and Treatment. Indoor Built Environ, 2003; 12:401-404.

Sikarwar MS and Patil M. Antidiabetic activity of Crateva nurvala stem bark extracts in alloxan-induced diabetic rats. J Pharm Bioallied Sci, 2010; 2:18.

Skrzydlewska E, Sulkowska M, Koda M, Sulkowski S. Proteolytic-antiproteolytic balance and its regulation in carcinogenesis. World J Gastroenterol, 2005; 11:1251-1266.

Soosamma J, Madhavi T, Bincy R, Jincy S. Phytochemistry and pharmacology of an important Indian medicinal plant Crataeva nurvala Buch-Ham. J Pharmacogn Phytochem, 2010; 2:275-280.

Stauffer CE. A linear standard curve for the Folin Lowry determination of protein. Anal Biochem,1975; 69:646-648.

Taga MS, Miller EE, Pratt DE. Chia seeds as a source of natural lipid antioxidants. J Am Oil Chem Soc, 1984;61:928-931.

Valko M, Leibfritz D, Moncol J, Cronin MT, Mazur M, Telser J. Free radicals and antioxidants in normal physiological functions and human disease. Int. J. Biochem. Cell Biol, 2007; 39:44-84.

Vanden Berghe T, Grootjans S, Goossens V, Dondelinger Y, Krysko DV, Takahashi N, Vandenabeele P. Determination of apoptotic and necrotic cell death in vitro and in vivo. Methods, 2013; 61:117-129.

Venkatachalapathi S and Subban R. Isolation and Quantification of lupeol in Strobilanthes ciliatus Nees by HPTLC method. Int J Pharm Pharm Sci, 2012; 4:405-408.

Warrier P, Nambiar V and Ramankutty C. 1995. Indian medicinal plants. A compendium of 500 species, Kottakal, Kerala: Orient Longman.

\section{How to cite this article:}

Hade SN, Joshi PA, Pilley HH, Wadegaonkar VP, Wadegaonkar PA. Evaluation of Crataeva nurvala extracts as antioxidant, antiproteolytic and cytotoxic against hepato-carcinoma and mouse melanoma cell lines. J App Pharm Sci, 2016; 6 (09): 189-196. 